\title{
Analysis on Worldwide Coronavirus (COVID-19) Cases
}

\author{
Shipra Gupta ${ }^{1}$, Jasmeet Kalra ${ }^{2}$, Himanshu Goyal ${ }^{3}$, Vijay Kumar $^{4^{*}}$ \\ ${ }^{1}$ Department of Commerce, Graphic Era Hill University Dehradun, India \\ ${ }^{2}$ Graphic Era Hill University Dehradun, India \\ ${ }^{3}$ Graphic Era Deemed to be University, Debradun, India \\ ${ }^{4}$ Professor and Dean Allied Sciences, Graphic Era Hill University Dehradun India
}

\begin{abstract}
Now a day, the virus of COVID-19 becomes a global health problem for human beings. The main concern of this virus is that it can transmit from human-to-human. The symptoms of this virus are similar to pneumonia. One body to another body of human being transmissions have been described after only incubation times between 3 to 14 days. It can spread through one infected hand to another during hand shake, and also due to contact with the infected surface of metal, glass, plastic, concrete, dirty places and even by fiber cloths. The problem of this virus has been increased suddenly and captures the whole world. Thus in this manuscript we reviewed the literature regarding this problem, so that people become aware about this. Many studies have been analyzed in this manuscript and conclude that this virus may be survive on all surfaces for up to contact with sanitizer, ethanol, $\mathrm{H}_{2} \mathrm{O}_{2}$ (hydrogen per oxide) within 30-40 seconds. Other chemicals may be sodium hypochlorite, benzalkonium chloride, chlorhexidine digluconate etc. At present, no specific formula of drugs, vaccines are not available in India and at globe. The method to vanish this virus is only to stop the chain and it is possible by the stop of movement of the human beings (lock down). Thus, the governments of all countries are trying to lock down their state and cities. Only by precaution, human being can defeat this virus.
\end{abstract}

Key Words: Corona virus, COVID-19, SARS-CoV-2, contaminated surfaces, chemicals for protection

\section{Introduction}

The symptoms of this virus are just like to viral flu. In the senior people (old age) and low immune system people, the symptoms of virus are seen like pneumonia with chest infections, fever and tightness in breath $(1,2)$. This novel coronavirus was observed in Wuhan city of China. In starting, Dr.Venliyang Li was the first person who alert about COVID-19 in China. On $31^{\text {st }}$ December, first virus prone case was found at Wuhan city in China. This virus is considered more dangerous due to its tendency of transmission from one human being to another. In January month a passenger steps down from cruise in Hong Kong. Around 1700 health workers and 50 thousands confirmed cases have affected from virus as per information available by State Health Commission, Hubei till 14-02-2020 (3).

History of Cases: As per Chinese Journal of Epidemiology, $80 \%$ cases are found mild. It is based on the analysis of 72,314 people of COVID-19 confirmed or suspected cases. In China, $80.9 \%$ cases are mild; recover soon and send back to home. 13.8\% cases are found severe including pneumonia and breathe problem. $4.7 \%$ cases are found critical with multi-organ failure and only about $0.2 \%$ cases are reported that this virus is dangerous. Only old age people are facing with the risk of death. In children, some cases are also found infected with the virus. The patients who are already suffering with their prior medical history like cardiovascular disease, hypertension, and diabetes etc are found at higher risks (4).

Possible Development of Symptoms (From Acute Cases): In Japan, the following analysis has been done. Two person of age 40 yrs. (confirmed cases) show the different development. In one case, diagnose pneumonia, and in second case only fever, muscle pain and cough. An infected patient of age 60 years, diagnose only low grade fever and sore throat. An old woman of age 70 years was diagnosed only pneumonia. The immune system of the human body is showing the different result after treatment (after about 5 to 14 days) (5).

How Long do Symptoms Last: World Health Organization (WHO) report about the recovery cases based on 55,924 cases that mild cases will take time for cure about 2 weeks, severe cases will be recovered in approximately 3-6 weeks, and some infected patient who were already suffering some other diseases are taking more time about 2 to 8 weeks (6).

\section{Materials and Method}

For this study, the data are taken from the website launched by Coronavirus symptoms (COVID-19) -

\footnotetext{
*Corresponding Author: Vijay Kumar, Dean Allied Sciences, Department of Physics, Graphic Era Hill University, Dehradun-248001, Uttrakhand, India

E-mail: drvijaykumar.geu@gmail.com,vijaykumar@gehu.ac.in, Mobile: 09012163541
} 
Table 1. The percentage of symptoms found in cases of COVID-19 (Based on study Wang et al and Chen et al $[11,13])$

\begin{tabular}{lccc}
\hline S. No. & Symptoms in Patients of COVID-19 & Percentage \\
\hline & & Wang et al [13] & Chen et al [11] \\
2 & Fever & 98.6 & 83 \\
3 & Fatigue & 69.6 & - \\
4 & Dry Cough & 59.4 & 82 \\
5 & Shortness of Breath & - & 31 \\
6 & Muscles pain & - & 9 \\
7 & Confusion & - & 8 \\
8 & Head ach & - & 5 \\
9 & Sore Throat & - & 4 \\
10 & Rhinorrhoea (Runny nose) & - & 2 \\
11 & Chest pain & - & 2 \\
12 & Diarrhea & - & 1 \\
13 & Nausea and vomiting & - & 90 \\
14 & More than one sign & - & 15 \\
\hline
\end{tabular}

Table 2. Infected and Death cases of health workers (Doctors and Nurses) as per State Health Commission

\begin{tabular}{lcc}
\hline Date & Virus prone cases & Death cases \\
\hline 13-02-2020(Outside of China, From Japan) & 203 & - \\
13-02-2020(Outside of China, From Singapore) & 47 & - \\
14-02-2020 & More than 1700 & 01 \\
20-02-20(South Korea)(Population25 lakh) & 53 & 02 \\
20-02-20(Iran) & 03 & 06 \\
Total & 1716 & - \\
\hline
\end{tabular}

Table 3. Worldwide death cases due to COVID-19 till 22-02-2020

\begin{tabular}{lll}
\hline Date & Virus prone cases & Death \\
\hline $8-02-20$ & 34598 & 721 \\
$9-02-20$ & 37287 & 813 \\
$10-02-20$ & 40171 & 904 \\
$11-02-20$ & 42748 & 1001 \\
$12-02-20$ & 44763 & 1115 \\
$13-02-20$ & Around 60000 & 1367 \\
$14-02-20$ & 65000 & Around 1500 \\
$15-02-20$ & More than 67000 & 1523 \\
$16-02-20$ & 68500 & 1665 \\
$17-02-20$ & 70548 & 1770 \\
$18-02-20$ & 72436 & 1868 \\
$19-02-20$ & 74000 & 2004 \\
$20-02-20$ & 75000 & 2100 \\
$21-02-20$ & More than 75000 & 2236 \\
$22-02-20$ & 76288 & 2345 \\
\hline
\end{tabular}

worldometer website (2). In this website, the symptoms of patients of COVID-19 are given in brief. The probability of curability, possible development of symptoms and death cases are also 
mention. The data are also collected from all authentic modes like daily news papers, $\mathrm{T} \mathrm{V}$ news channels and radio news etc. In one table the data is collected with the symptoms of virus and comparison of two studies is given. Date wise death cases of health workers of whole world are given in another table. Number of new virus prone cases, cured patients, serious/critical cases and death cases of various countries are tabulated. The data are again collected from different sources of news and references (7).

\section{Results}

Most data represent that the main symptoms of the patients of coronavirus are suffering from fever and dry cough. Table 1 represents the percentage of possible infections in patients of COVID-19. As per one study (8), the symptoms in patients are only fever, fatigue and dry cough while another study (9) represents that the symptoms of the patients may be fever, fatigue, dry cough, Shortness of Breath, Muscles \& head ache, Sore throat, chest pain, runny nose, diarrhea and vomiting etc. In some cases, multiple symptoms are seen. To diagnose and treatment of the patients, many health care employee become infected. Table 2 shows the worldwide number of death cases of health workers. In table 3 , date wise death and infected cases are mentioned for the month of February 2020. The data of table 3 is from 8 Feb to 22 February 2020. The number of virus prone and death cases are increased continuously. The data of Table 4 is taken from the website of worldometer till 22 March 2020. The infected cases, cured patients, serious/critical cases and death cases are mentioned in this table (10).

\section{Discussion}

After the analysis of above given tables, it is seen that the maximum patients who are infected by COVID19 virus show many symptoms but maximum patients are suffering from fever and cough. However, it is considered that the virus is started from Wuhan city of China and number of infected/death cases were in China but after the precautions and many decision like lock down, sanitization etc., the situation becomes under control in China. Table 2 reveals that the number of death and infected cases are gradually increases in whole world. In the month of February, China was very disturbed and other countries only were trying to learn from China bur perhaps, other countries become late to take lesson from China and result is that now the infected and death cases in other countries are increased very rapidly. Now in
Italy, the data of death cases become greater to China. Right now, the people of 188 countries are infected due to this COVID-19 virus and this number is continuously increasing. Frequently touching of any contaminated surfaces becomes cause of transmission of this virus (12). The probability of transfer of a virus on hand within 5 seconds is $31.6 \%(8,10)$. In general a student touches his face 23 times in an hour. As he/she touches his face, the virus is transferred to face from hand. The timing of virus to enter inside the body through eyes, nose and mouth is about 10 minutes. The percentage of touching the parts of face by any Student is about nose (31\%), skin 56\%, mouth $(36 \%)$, and eyes $(31 \%)(14)$. The chain of spreading a virus from hand to face, eyes and nose can be stopped by the use of alcoholic sanitizer or washing hands by soap (with bleach) (15). The dangerous property of this virus is that it can transmit from one human body to another and it become multiple, i.e., the previous and after both contact person become infected. The summarized data of this manuscript reveals that however the number of infected cases are more in China but death cases are maximum in Italy. The time of increasing of death cases in Italy is very low which show the dangerous situation of the globe. The number of infected and death cases are more in developed countries and the cases are continuously increasing in undeveloped countries. It was described in Taiwan that installation of hand wash mechanism could control the spreading of COVID-19 virus (16, 17).

Suggestions: From the above data and analysis, it is suggested that:

1. Hand hygiene by alcoholic sanitizer or washing hands by use of bleached soap can be helpful to stop chain of spreading the COVID-19 virus. (18-19).

2. The social distance can protect the human beings from corona virus.

3. World health Organization (WHO) also recommends to preferably using alcoholic based chemical for decontamination of hands.

4. Lock down situation of a city and state can break the spreading chain of virus.

5. As the symptoms are seen in any person, immediately contact to the hospitals.

6. The infected people take proper carination or isolation position.

7. All people should follow the instruction given by the doctors and health care employee.

8. All citizens should follow the guidelines of the Government of Health Ministry of Country.

9. For time being. Try to become vegetarian, but no data were found to clarify it.

After above data analysis, it is concluded that COVID-19 virus may survive on hand skin and cloths 
Table 4. Worldwide data of COVID-19 (new, recovered, serious and death) cases, till date (21-03-2020, midnight) [2]

\begin{tabular}{|c|c|c|c|c|c|c|c|c|}
\hline $\begin{array}{l}\text { Name of } \\
\text { Country }\end{array}$ & $\begin{array}{c}\text { Number } \\
\text { of total } \\
\text { Cases }\end{array}$ & $\begin{array}{c}\text { Number } \\
\text { of new } \\
\text { Cases }\end{array}$ & $\begin{array}{c}\text { Number } \\
\text { of total } \\
\text { Deaths }\end{array}$ & $\begin{array}{c}\text { Number } \\
\text { of new } \\
\text { Deaths }\end{array}$ & $\begin{array}{c}\text { Number } \\
\text { of } \\
\text { Recovered } \\
\text { patients }\end{array}$ & $\begin{array}{c}\text { Number } \\
\text { of } \\
\text { active } \\
\text { Cases }\end{array}$ & $\begin{array}{c}\text { Number of } \\
\text { serious/critical } \\
\text { patients }\end{array}$ & $\begin{array}{c}\text { Number } \\
\text { of cases } \\
\text { per } 1 \\
\text { million } \\
\text { populati } \\
\text { on }\end{array}$ \\
\hline China & 81,054 & +46 & 3,261 & +6 & 72,440 & 5,353 & 1,845 & 56 \\
\hline Italy & 53,578 & & 4,825 & & 6,072 & 42,681 & 2,857 & 886 \\
\hline USA & 26,900 & $+2,693$ & 348 & +46 & 178 & 26,374 & 708 & 81 \\
\hline Spain & 25,496 & & 1,381 & & 2,125 & 21,990 & 1,612 & 545 \\
\hline Germany & 22,364 & & 84 & & 209 & 22,071 & 2 & 267 \\
\hline Iran & 20,610 & & 1,556 & & 7,635 & 11,419 & & 245 \\
\hline France & 14,459 & & 562 & & 1,587 & 12,310 & 1,525 & 222 \\
\hline S. Korea & 8,897 & +98 & 104 & +2 & 2,909 & 5,884 & 59 & 174 \\
\hline Switzerland & 6,863 & & 80 & & 131 & 6,652 & 141 & 793 \\
\hline UK & 5,018 & & 233 & & 93 & 4,692 & 20 & 74 \\
\hline Netherlands & 3,631 & & 136 & & 2 & 3,493 & 354 & 212 \\
\hline Austria & 3,024 & +32 & 8 & & 9 & 3,007 & 15 & 336 \\
\hline Belgium & 2,815 & & 67 & & 263 & 2,485 & 288 & 243 \\
\hline Norway & 2,176 & +12 & 7 & & 6 & 2,163 & 28 & 401 \\
\hline Sweden & 1,770 & & 20 & & 16 & 1,734 & 71 & 175 \\
\hline Canada & 1,328 & & 19 & & 14 & 1,295 & 1 & 35 \\
\hline Denmark & 1,326 & & 13 & & 1 & 1,312 & 42 & 229 \\
\hline Australia & 1,286 & +214 & 7 & & 46 & 1,233 & 2 & 50 \\
\hline Portugal & 1,280 & & 12 & & 5 & 1,263 & 26 & 126 \\
\hline Malaysia & 1,183 & & 9 & +1 & 114 & 1,060 & 26 & 37 \\
\hline Brazil & 1,178 & & 18 & & 2 & 1,158 & 18 & 6 \\
\hline Japan & 1,054 & & 36 & & 215 & 803 & 55 & 8 \\
\hline Czechia & 995 & & & & 6 & 989 & 7 & 93 \\
\hline Turkey & 947 & & 21 & & & 926 & & 11 \\
\hline Israel & 883 & & 1 & & 36 & 846 & 15 & 102 \\
\hline Ireland & 785 & & 3 & & 5 & 777 & 13 & 159 \\
\hline $\begin{array}{l}\text { Diamond } \\
\text { Princess }\end{array}$ & 712 & & 8 & & 567 & 137 & 15 & \\
\hline Luxembourg & 670 & & 8 & & 6 & 656 & 3 & 1,070 \\
\hline Pakistan & 645 & & 3 & & 13 & 629 & & 3 \\
\hline Thailand & 599 & +188 & 1 & & 44 & 554 & 7 & 9 \\
\hline Chile & 537 & & 1 & & 8 & 528 & 7 & 28 \\
\hline Poland & 536 & & 5 & & 13 & 518 & 3 & 14 \\
\hline Ecuador & 532 & & 7 & & 3 & 522 & 2 & 30 \\
\hline Greece & 530 & & 13 & & 19 & 498 & 18 & 51 \\
\hline Finland & 523 & & 1 & & 10 & 512 & 2 & 94 \\
\hline Qatar & 481 & & & & 27 & 454 & 6 & 167 \\
\hline Iceland & 473 & & 1 & & 5 & 467 & 1 & 1,386 \\
\hline Indonesia & 450 & & 38 & & 20 & 392 & & 2 \\
\hline Singapore & 432 & & 2 & & 140 & 290 & 14 & 74 \\
\hline
\end{tabular}

East J Med Volume:25, Number:4, October-December/2020 


\begin{tabular}{|c|c|c|c|c|c|c|c|c|}
\hline Saudi Arabia & 392 & & & & 16 & 376 & & 11 \\
\hline Slovenia & 383 & & 1 & & & 382 & 12 & 184 \\
\hline Philippines & 380 & +73 & 25 & +6 & 15 & 340 & 1 & 3 \\
\hline Romania & 367 & & & & 52 & 315 & 14 & 19 \\
\hline India & 332 & & 5 & & 24 & 303 & & 0.2 \\
\hline Peru & 318 & & 5 & & 1 & 312 & 5 & 10 \\
\hline Bahrain & 310 & & 1 & & 125 & 184 & 4 & 182 \\
\hline Russia & 306 & & 1 & & 16 & 289 & & 2 \\
\hline Estonia & 306 & & & & 2 & 304 & & 231 \\
\hline Egypt & 294 & & 10 & & 42 & 242 & & 3 \\
\hline Hong Kong & 274 & & 4 & & 100 & 170 & 4 & 37 \\
\hline Mexico & 251 & +48 & 2 & & 4 & 245 & 1 & 2 \\
\hline Panama & 245 & & 3 & & 1 & 241 & 7 & 57 \\
\hline South Africa & 240 & & & & 2 & 238 & & 4 \\
\hline Lebanon & 230 & & 4 & & 8 & 218 & 4 & 34 \\
\hline Argentina & 225 & +67 & 4 & & 27 & 194 & & 5 \\
\hline Iraq & 214 & & 17 & & 51 & 146 & & 5 \\
\hline Colombia & 210 & +14 & 1 & +1 & 3 & 206 & & 4 \\
\hline Croatia & 206 & & 1 & & 5 & 200 & & 50 \\
\hline Armenia & 190 & +30 & & & 2 & 188 & 2 & 64 \\
\hline Serbia & 188 & +17 & 1 & & 2 & 185 & 4 & 22 \\
\hline Slovakia & 178 & & & & 7 & 171 & 2 & 33 \\
\hline Kuwait & 176 & & & & 27 & 149 & 5 & 41 \\
\hline Bulgaria & 163 & & 3 & & 3 & 157 & 3 & 23 \\
\hline San Marino & 160 & & 20 & & 4 & 136 & 12 & 4,715 \\
\hline Taiwan & 153 & & 2 & & 28 & 123 & & 6 \\
\hline UAE & 153 & & 2 & & 38 & 113 & 2 & 15 \\
\hline Algeria & 139 & & 15 & & 65 & 59 & & 3 \\
\hline Uruguay & 135 & +25 & & & & 135 & 2 & 39 \\
\hline Hungary & 131 & +28 & 4 & & 7 & 120 & 6 & 14 \\
\hline Latvia & 124 & & & & 1 & 123 & & 66 \\
\hline Costa Rica & 117 & & 2 & & 2 & 113 & 2 & 23 \\
\hline $\begin{array}{l}\text { Dominican } \\
\text { Republic }\end{array}$ & 112 & & 3 & & & 109 & & 10 \\
\hline Lithuania & 105 & +6 & 1 & & 1 & 103 & 1 & 39 \\
\hline Jordan & 100 & & & & 1 & 99 & & 10 \\
\hline Morocco & 96 & & 3 & & 3 & 90 & 1 & 3 \\
\hline Vietnam & 94 & & & & 17 & 77 & 2 & 1.0 \\
\hline $\begin{array}{l}\text { Bosnia and } \\
\text { Herzegovina }\end{array}$ & 93 & & 1 & & 2 & 90 & 1 & 28 \\
\hline $\begin{array}{l}\text { Faeroe } \\
\text { Islands }\end{array}$ & 92 & & & & 3 & 89 & & 1,883 \\
\hline Andorra & 88 & & & & 1 & 87 & 2 & 1,139 \\
\hline $\begin{array}{l}\text { North } \\
\text { Macedonia }\end{array}$ & 85 & & & & 1 & 84 & 1 & 41 \\
\hline Cyprus & 84 & & 1 & & 3 & 80 & 3 & 70 \\
\hline Brunei & 83 & & & & 1 & 82 & 2 & 190 \\
\hline Moldova & 80 & & 1 & & 1 & 78 & 3 & 20 \\
\hline
\end{tabular}

East J Med Volume:25, Number:4, October-December/2020 


\begin{tabular}{|c|c|c|c|c|c|c|c|}
\hline Sri Lanka & 77 & & & 3 & 74 & 2 & 4 \\
\hline Albania & 76 & & 2 & 2 & 72 & 2 & 26 \\
\hline Belarus & 76 & & & 15 & 61 & & 8 \\
\hline Malta & 73 & & & 2 & 71 & 1 & 165 \\
\hline Venezuela & 70 & & & 15 & 55 & 2 & 2 \\
\hline $\begin{array}{l}\text { New } \\
\text { Zealand }\end{array}$ & 66 & +14 & & & 66 & & 14 \\
\hline Burkina Faso & 64 & & 3 & 5 & 56 & & 3 \\
\hline Tunisia & 60 & & 1 & 1 & 58 & 7 & 5 \\
\hline Guadeloupe & 56 & & 1 & & 55 & 4 & 140 \\
\hline Senegal & 56 & & & 5 & 51 & & 3 \\
\hline Georgia & 54 & +5 & & 1 & 53 & 1 & 14 \\
\hline Kazakhstan & 54 & & & & 54 & & 3 \\
\hline Azerbaijan & 53 & & 1 & 11 & 41 & & 5 \\
\hline Cambodia & 53 & & & 2 & 51 & & 3 \\
\hline Palestine & 53 & & & 17 & 36 & & 10 \\
\hline Oman & 52 & & & 13 & 39 & & 10 \\
\hline $\begin{array}{l}\text { Trinidad and } \\
\text { Tobago }\end{array}$ & 49 & & & & 49 & & 35 \\
\hline Ukraine & 47 & & 3 & 1 & 43 & & 1 \\
\hline Réunion & 47 & & & & 47 & & 52 \\
\hline Uzbekistan & 42 & +1 & & & 42 & & 1 \\
\hline Cameroon & 40 & & & 2 & 38 & & 2 \\
\hline Martinique & 37 & & 1 & & 36 & 7 & 99 \\
\hline Liechtenstein & 37 & & & & 37 & & 970 \\
\hline $\begin{array}{l}\text { Channel } \\
\text { Islands }\end{array}$ & 32 & & & & 32 & & 184 \\
\hline Honduras & 26 & +2 & & & 26 & & 3 \\
\hline Bangladesh & 24 & & 2 & 3 & 19 & & 0.1 \\
\hline Afghanistan & 24 & & & 1 & 23 & & 0.6 \\
\hline DRC & 23 & & 1 & & 22 & & 0.3 \\
\hline Paraguay & 22 & & 1 & & 21 & 1 & 3 \\
\hline Nigeria & 22 & & & 1 & 21 & & 0.1 \\
\hline Cuba & 21 & & 1 & & 20 & & 2 \\
\hline Ghana & 21 & & 1 & & 20 & & 0.7 \\
\hline Puerto Rico & 21 & & 1 & & 20 & & 7 \\
\hline Jamaica & 19 & & 1 & 2 & 16 & & 6 \\
\hline Macao & 19 & & & 10 & 9 & & 29 \\
\hline Bolivia & 19 & & & & 19 & & 2 \\
\hline Guyana & 18 & & 1 & & 17 & & 23 \\
\hline Monaco & 18 & & & 1 & 17 & & 459 \\
\hline $\begin{array}{l}\text { French } \\
\text { Guiana }\end{array}$ & 18 & & & & 18 & & 60 \\
\hline Guatemala & 17 & & 1 & & 16 & & 0.9 \\
\hline Rwanda & 17 & & & & 17 & & 1 \\
\hline Montenegro & 16 & & & & 16 & & 25 \\
\hline Togo & 16 & & & & 16 & & 2 \\
\hline French & 15 & & & & 15 & & 53 \\
\hline
\end{tabular}

East J Med Volume:25, Number:4, October-December/2020 


\begin{tabular}{|c|c|c|c|c|c|c|}
\hline \multicolumn{7}{|l|}{ Polynesia } \\
\hline Guam & 15 & & & & 15 & 89 \\
\hline Mauritius & 14 & & 1 & & 13 & 11 \\
\hline Barbados & 14 & & & & 14 & 49 \\
\hline Ivory Coast & 14 & & & 1 & 13 & 0.5 \\
\hline Kyrgyzstan & 14 & & & & 14 & 2 \\
\hline Maldives & 13 & & & 3 & 10 & 24 \\
\hline Mayotte & 11 & & & & 11 & 40 \\
\hline Gibraltar & 10 & & & 2 & 8 & 297 \\
\hline Mongolia & 10 & & & & 10 & 3 \\
\hline Ethiopia & 9 & & & & 9 & 0.08 \\
\hline Aruba & 8 & +3 & & 1 & 7 & 75 \\
\hline Kenya & 7 & & & & 7 & 0.1 \\
\hline Seychelles & 7 & & & & 7 & 71 \\
\hline $\begin{array}{l}\text { Equatorial } \\
\text { Guinea }\end{array}$ & 6 & & & & 6 & 4 \\
\hline Tanzania & 6 & & & & 6 & 0.1 \\
\hline $\begin{array}{l}\text { U.S. Virgin } \\
\text { Islands }\end{array}$ & 6 & & & & 6 & 57 \\
\hline Gabon & 5 & & 1 & & 4 & 2 \\
\hline Saint Martin & 5 & & & & 5 & 129 \\
\hline Suriname & 5 & & & & 5 & 9 \\
\hline Bahamas & 4 & & & & 4 & 10 \\
\hline $\begin{array}{l}\text { New } \\
\text { Caledonia }\end{array}$ & 4 & & & & 4 & 14 \\
\hline Eswatini & 4 & +3 & & & 4 & 3 \\
\hline $\begin{array}{l}\text { Cayman } \\
\text { Islands }\end{array}$ & 3 & & 1 & & 2 & 46 \\
\hline Curaçao & 3 & & 1 & & 2 & 18 \\
\hline Cabo Verde & 3 & & & & 3 & 5 \\
\hline CAR & 3 & & & & 3 & 0.6 \\
\hline Congo & 3 & & & & 3 & 0.5 \\
\hline El Salvador & 3 & & & & 3 & 0.5 \\
\hline Liberia & 3 & & & & 3 & 0.6 \\
\hline Madagascar & 3 & & & & 3 & 0.1 \\
\hline Namibia & 3 & & & & 3 & 1 \\
\hline St. Barth & 3 & & & & 3 & 304 \\
\hline Zimbabwe & 3 & & & & 3 & 0.2 \\
\hline Sudan & 2 & & 1 & & 1 & 0.05 \\
\hline Angola & 2 & & & & 2 & 0.06 \\
\hline Benin & 2 & & & & 2 & 0.2 \\
\hline Bermuda & 2 & & & & 2 & 32 \\
\hline Bhutan & 2 & & & & 2 & 3 \\
\hline Fiji & 2 & & & & 2 & 2 \\
\hline Greenland & 2 & & & & 2 & 35 \\
\hline Guinea & 2 & & & & 2 & 0.2 \\
\hline Haiti & 2 & & & & 2 & 0.2 \\
\hline Isle of Man & 2 & & & & 2 & 24 \\
\hline
\end{tabular}

East J Med Volume:25, Number:4, October-December/2020 


\begin{tabular}{|c|c|c|c|c|c|c|c|c|}
\hline Mauritania & 2 & & & & & 2 & & 0.4 \\
\hline Nicaragua & 2 & & & & & 2 & & 0.3 \\
\hline Saint Lucia & 2 & & & & & 2 & & 11 \\
\hline Zambia & 2 & & & & & 2 & & 0.1 \\
\hline Nepal & 1 & & & & 1 & 0 & & 0.03 \\
\hline $\begin{array}{l}\text { Antigua and } \\
\text { Barbuda }\end{array}$ & 1 & & & & & 1 & & 10 \\
\hline Chad & 1 & & & & & 1 & & 0.06 \\
\hline Djibouti & 1 & & & & & 1 & & 1 \\
\hline Eritrea & 1 & & & & & 1 & & 0.3 \\
\hline Gambia & 1 & & & & & 1 & & 0.4 \\
\hline Vatican City & 1 & & & & & 1 & & 1,248 \\
\hline Montserrat & 1 & & & & & 1 & & 200 \\
\hline Niger & 1 & & & & & 1 & & 0.04 \\
\hline $\begin{array}{l}\text { Papua New } \\
\text { Guinea }\end{array}$ & 1 & & & & & 1 & & 0.1 \\
\hline $\begin{array}{l}\text { St. Vincent } \\
\text { Grenadines }\end{array}$ & 1 & & & & & 1 & & 9 \\
\hline Sint Maarten & 1 & & & & & 1 & & 23 \\
\hline Somalia & 1 & & & & & 1 & & 0.06 \\
\hline Timor-Leste & 1 & & & & & 1 & & 0.8 \\
\hline Uganda & 1 & & & & & 1 & & 0.02 \\
\hline Total: & 308,609 & 3,619 & 13,069 & 62 & 95,829 & 199,711 & 9,943 & 39.6 \\
\hline
\end{tabular}

of people many hours. It is also survive on the surface of metal, plastic, glass and concrete surface. As above given symptoms are seen in any people, he/she should become isolate from the other person. As the proper treatment of this virus is not available in globe, so except use precautions, no other way is available right now. The above tables also show that the speed of spreading of this virus is very high. In very short time, the number of infected/death cases are increased very rapidly in whole world. The chain of this virus may be stopped by the isolation to/from the human beings. The negligence may become dangerous for whole human beings.

\section{References}

1. Kampf G; Todt D, Pfaender S, Steinmann E. Persitence of coronaviruses on in animate surfaces and their in activation with biocidal agents, J of Hospital Infection 2020; 104: 246-251.

2. https://www.worldometers.info/coronavirus/cor onavirus-symptoms.

3. Yen M Y, Lu Y C, Huang P H, Chen C M, Chen Y C, Lin Y E, Quantitative evaluation of infection control models in the prevention of nosoomial transmission of SARS virus to health care workers: implecatin to nosoconia viral infection control for health care workers, Scand J Infect Dis 2010; 42: 510-515.

4. Alshammari M, Reynold K A, Verhougstraete M, O'Rourke M K. Comparison of persisved and observed and higene compliance in health care workers in MERS- CoV endemic reasons. Health care (Basel, Switzerland) 2018; 6: 122.

5. Al-Tawfiq J A, Abdrabalnabi R, Taher A, Mathew $\mathrm{S}$, Rahman K A. Infection control influence of middle east respiratory syndrome coronavirus; A hospital-based analysis. AM J infect Contr 2019; 47: 431-434.

6. Wong T W, Tam W W. Hand washing practice and the use of personnel protective equipment among medical student after the SARS epidemic in Hongkong. AM J infect Contr 2005; 33: 580 586.

7. Wiboon Chutikul S, Manosuthi W, Likanonsakul, S, Sangsajja C, Kongsanan P, Nitiyanontakij R, et al. Lack of transmission among health care workers in contact with a case of middle east respiratory syndrome coronavirus infection in Thailand. Antimicrob Resist infect control 2016; 5: 21 .

8. Ki H K, Han S K, Son J S, Park SO. Risk of transmission via medical employees and importance of routine infection-prevention policy in a nonocomial outbreak of middle east respiratory syndrome (MERS); a descriptive 
analysis from tertiary care hospital in south Corea BMC Pulm Med 2019; 19: 190.

9. Kwok Y L, Gralton J, Mclaws M L. Face touching: A frequent habit that has implecation for hand hygiene. Am J Contr 2015; 43: 112-114.

10. Bean B, Moore B M, Sterner B, Peterson L R, Gerding D N, Balfour H H. Survival of influenza viruses an environmental surfaces. J Infect Dis 1982; 146: 47-51.

11. Chen et al, The Lancet, January 2020, Report of the WHO-China joint mission on Coronavirus disease 2019 (COVID-19) [World Health Organization, Feb, 2020].

12. Huang et al, The Lancet, January 24, 2020, Clinical features of patients infected with 2019 novel coronavirus in Wuhan, China.

13. Wang et al Clinical characteristics of 138 hospitalized patients with 2019 novel coronavirusinfected Pneumonia in Wuhan China-JAMA, February 72020.

14. WHO, Coronavirus Disease 2019 (COVID-19). WHO; 2020. Situation Report 23.
15. WHO. Infection prevention and control during health care when novel coroavirus ( $\mathrm{n} \mathrm{CoV}$ ) Infection is suspected. WHO; 2020 Interim guidance. 25 January 2020.

16. Lai MY, Cheng PK, Lim WW. Survival of severe acute respiratory syndrome coronavirus. Clin Infect Dis 2005; 41: 67-71.

17. Chan JF, Yuan S, Kok KH, To KK, Chu H, Yang J. et al. A familial cluster of pneumonia associated with the 2019 novel coronavirus indicating person-to-person transmission; a study of a family cluster. Lancet 2020. https;//doi.org/10.1016/s0140-6736(20)30154-9.

18. Wood A, Payne D. The action of three antiseptics/ disinfectants against enveloped and nonenveloped viruses. J Hosp Infect 1998; 38: 283-295.

19. Warnes S L, Little ZR, Keevil CW. Human Coronavirus 229E and OC 43 in suspension and after drying on surfaces: a possible sources of hospital-acquired infections. J Hosp Infect 2000; 46: 55-60. 